\title{
ИСЛАНД УЛСЫН БАГА ТЕМПЕРАТУРТАЙ, ГАЗРЫН ГУНИЙ ДУЛААНЫ ИЛЭРЦТЭЙ ТАЛБАЙ ДЭЭРХ ТЕМ БА МТ АРГУУДЫН ХЭРЭГЛЭЭ
}

\author{
Л.Саранц̧эцฺэ ${ }^{l}$ *, Hersir G.P. ${ }^{2}$, Arnason K. $^{2}$ \\ 1. Одон Орон Геофизикийн Хүрээлэн, ШУА, Монгол улс \\ 2. Iceland Geosurvey-ISOR \\ *Lахим шуудан: sarantsetseg@iag.ac.mn
}

\section{ХУРААНГУЙ}

Газрын гүний дулааны хайгуул хийхэд геологи, геохими, геофизикийн хайгуулын судалгаануудыг явуулах шаардлага гардаг. Геофизикийн хайгуульн судалгаанд эсэргүүилийн арга нь газрын гүний дулааны эх үүсвэрийн нөөцийн хил хязгаарыг тогтооход хамгийн чухал ҮҮрэг гүйщэтгэдэг. Газрын гүний дулааны системийг хянадаг параметруүд нь иахилгаан эсэргүүиэлд хүчтэй хариу үйлдэл үзүүлдэг.

Исланд улсад газрын гүний дулааны хайгуулд ихэвчлэн ТЕМ (Албадмал иахилгаан соронзон) ба МТ (Байгалийн соронзон буюу соронзон теллур) аргуудыг ашигладаг. Исланд улсын Эйяафёрдур талбайд дээрх аргуудаар хийгдсэн хэмжилтийн мэдээллийг боловсруулж гарсан үр дүнгээс тухайн талбайн газрын гүний дулааны системийн бүтиэд тайлал хийсэн болно.

Түлхүур үгс: Газрын гүний дулаан, цахилгаан эсэргүүиэл, соронзон теллурын арга;

\section{ОРШИЛ}

Энэ ажлын хүрээнд Эйяафёрдур бага температуртай талбайн газрын гүний дулааны системийн бүтэц, байрлалыг тогтоох зорилго тавьсан. Системийн бүтэц, байрлалыг мэдсэнээр ашиглалтын худгийн өрөмдлөгийн цэгийг сонгоход ихээхэн ач холбогдолтой. Газрын гүний дулааны гадаргуу дээрх илэрцүүд нь ихэнхидээ хавтангуудын хил заагууд болон хагарлуудын дагуу үзэгддэг. Үүний нэг том жишээ нь Исландын арал бөгөөд Хойд Америк ба Евро - Азийн хавтангуудын хил заагаар хуваагдсан байдаг. Газрын гүний дулааны системүүд нь өндөр температуртай (>2000C) бага температуртай $(<1500 \mathrm{C})$ гэж ангилагддаг ба хавтангуудын хил заагийн дагуу өндөр температуртай бүсүүд, хил заагаас холдох тусам температур буурдаг. Газрын гүний дулааны системүүд нь температур, даралт, чулуулгийн нүх сүвшилт, цахилгаан соронзон нэвтрүүлэх чадвар, шингэний химийн элементүүдийн агууламжаар хянагддаг. Эдгээ параметрүүд нь цахилгаан эсэргүүцэлд 
хүчтэй хариу үзүүлдэг учраас эсэргүүцлийн аргууд нь газрын гүний дулааны илрэцтэй талбайн хил хязгаарыг зураглахад хамгийн хүчирхэг арга болдог.

\section{МАТЕРИАЛ, АРГА ЗУЙ}

УГ талбай дээр хоорондоо 20 - 30 км зайд байрласан 23 ТЕМ болон МТ ийн судалгааны тандалтын хэмжилтүүд хийгдсэн (хэмжилтийн талбайн байршлын зураг 1). Хэмжилтүүдийн мэдээллийг цэг тус бүрд нь боловсруулсан ба үр дүнг нь давхар урвуу бодлого бодоход ашигласан.

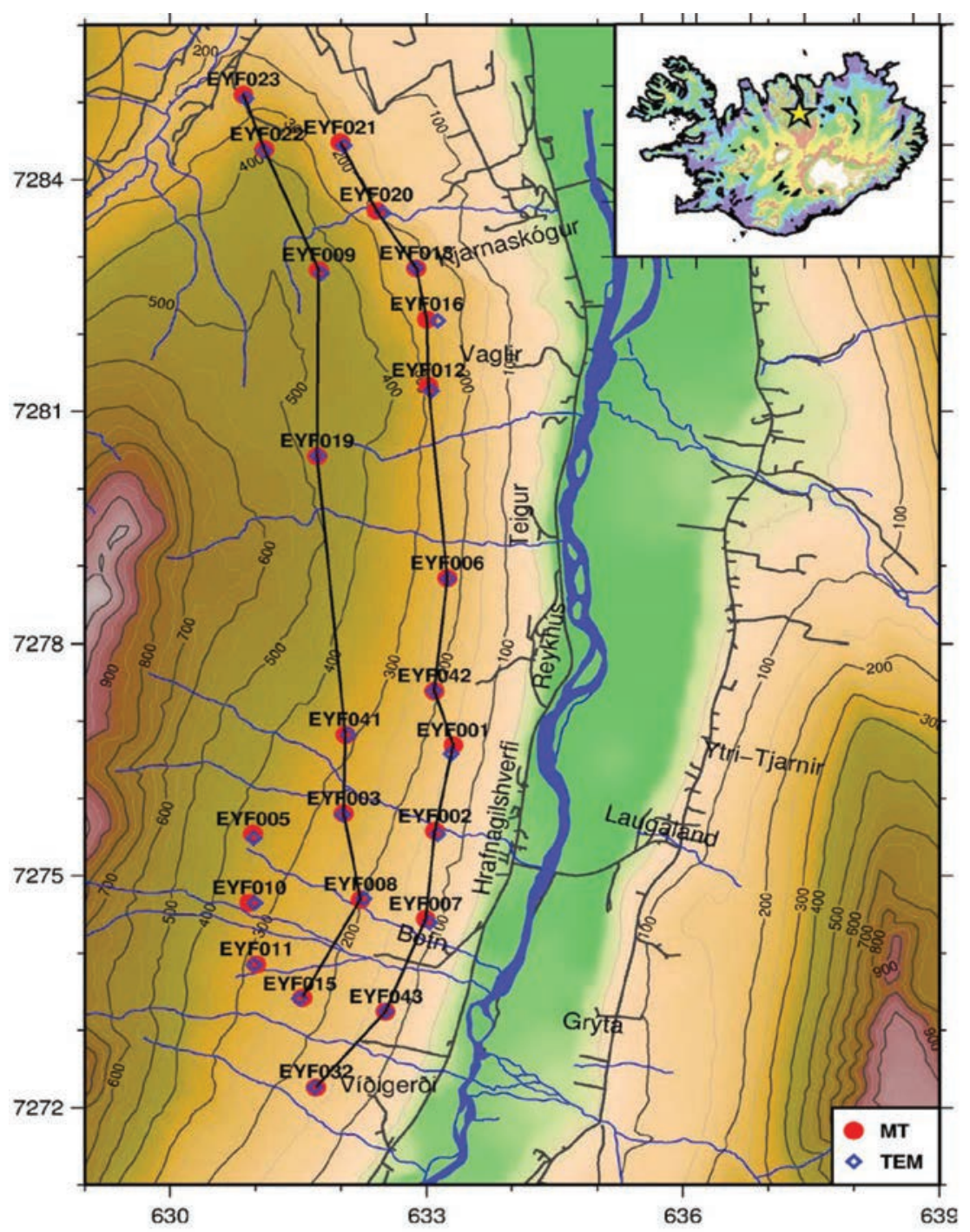

Зураг 1: Эйяфёрдур талбай дах ТЕМ ба МТ - ийн судалгааны хэмжилтийн иэгуүд. Зургийн баруун дээд өнщөгт Исландын газрын зураг дээрх шар одоор судалгааны талбайг тэмдэглэсэн. 2 хөндлөн зусэлт нь хар шугамаар зурагдсан. 


\section{ТЕМ - Албадмал цахилгаан соронзон арга}

TEM нь газрын гүний дулааны хайгуулын судалгаанд өргөн хэрэглэгддэг идэвхтэй арга юм. Хэмжилтэнд 2,5 ба 25 Гц дээр том ба жижиг талбай бүхий дамжуулагч төхөөрөмжүүд ашиглагддаг. Бидний энэ удаагийн хэмжилтэд ашигласан дамжуулагч төхөөрөмж нь 200м х 200м талбайтай ба 20 - 25 А гүйдэл өгсөн бөгөөд энэ нь 50-800 м гүний мэдээллийг өгч чадна. Тогтмол гүйдэл нь цахилгаан гүйдлийн үүсгүүрээс (Цахилгаан генератор) дамжуулагч руу (трансмиттер ороомог руу) импульс хэлбэрээр өгөгдөх ба битүу хэлхээний тойрог соронзон орон үүснэ. Импульсийн үргэлжлэх хугацаа буюу албадмал гүйдлийн үүсгүүр огцом зогссоны дараа хэмжилт эхэлдэг ба цахилгаан соронзон дохио гүн рүү нэвтэрдэг [1]. Энэ үед соронзон орны нөлөөгөөр хөрсөнд гүйдэл өдөөгддөг. Фарадэйн хуулиар хөрсөн дахь өдөөгдсөн гүйдлийн нөлөөгөөр хүлээн авагч төхөөрөмж (хүлээн авагч ороомог) дотор хоёрдогч соронзон орныг үүсгэдэг. Хоёрдогч соронзон орны замхралт нь хөрсний эсэргүүцлээс шууд хамаардаг. Хөрсний эсэргүүцэл нь хүлээн авагч төхөөрөмжид бүртгэгдсэн хүчдэлийн утгаар тооцоологддог[2]:

$$
\begin{aligned}
& V(t, r)=I_{0} \frac{C\left(\mu_{0} \sigma r^{2}\right)^{3 / 2}}{10 \pi^{1 / 2} t^{5 / 2}} \\
& \text { Энд: } C=A_{r} n_{r} A_{s} n_{s} \frac{\mu_{0}}{2 \pi r^{3}}
\end{aligned}
$$

$n_{r}=$ хүлээн авагч төхөөрөмж доторх ороомгийн тоо;

$A_{s}=$ дамжуулагч хэлхээний талбай $\left(\mathrm{m}^{2}\right)$;

$n_{r}=$ дамжуулагч хэлхээн доторх ороомгийн тоо;

$t=$ гүйдэл зогсоогдсоны дараа өнгөрсөн хугацаа (s);

$\mu_{0}=$ соронзон дамжуулал (Henry/m);

$V(t, r)=$ өдөөгдсөн хүчдэл (B);

$r=$ дамжуулагч хэлхээний радиус (m);

$I_{0}=$ дамжуулагч хэлхээн дэх гүйдэл (А).
Төлөөллийн эсэргүүцэл нь Тэгшитгэл 1 - ээс гарч ирдэг.

$$
\rho_{a}=\frac{\mu_{0}}{4 \pi}\left[\frac{2 I_{0} \mu_{0} A_{r} A_{s} n_{r} n_{s}}{5 t^{\frac{2}{3}} V(t, r)}\right]^{\frac{2}{3}}
$$

Төлөөллийн эсэргүүцлийн муруй нь дамжуулагчийн албадмал цахилгаан гүйдэл зогссоны дараах хугацааны функц байдлаар тооцоологддог.

\section{МТ - Соронзон теллурын арга}

Соронзон теллурын арга нь 1000 м-ээс 30 км -ийн гүний мэдээллийг өгдөг ба $10^{-4}$ $10^{3}$ Гц өргөн давтамжийн мужид хэмжилт хийгддэг эсэргүүцлийн, идэвхгүй арга юм. Цахилгаан соронзон орны өөрчлөлт нь дэлхийн соронзон орны өөрчлөлт байдлаар ажиглагддаг бөгөөд эдгээр нь микропульс гэж нэрлэгддэг. Энэ нь газрын хөрсөнд цахилгаан соронзон теллурын гүйдлийг өдөөдөг [3]. Цахилгаан соронзон теллурын гүйдлийн нягт ба тархалт нь бүс нутгийн хөрсний цахилгаан дамжууллын бүтцээс хамаардаг. Хөрсний гүний бүтэц нь газрын гадаргуу дээрх соронзон орны өөрчлөлт, В $[\gamma]$ болон тодорхой давтамжийн, $\omega[\Gamma ц]$ хүрээнд газрын хөрсөн дэх цахилгаан орны өөрчлөлтийг, E [B/м] нэгэн зэрэг хэмжсэнээр судлагддаг. Анхдагч соронзон орон нь цэнэгт мандлаас эхтэй ба газрын хөрсөнд цахилгаан орон ба гүйдлийг үүсгэдэг. Энэ гүйдэл нь хөрсний анхдагч орон ба цахилгаан эсэргүүцлээс хамаардаг. Гүйдэл, I нь хоёрдогч соронзон индукцийг, $\mathrm{BS}$ өдөөдөг. $\mathrm{B}=\mathrm{B}_{\mathrm{P}}+\mathrm{B}_{\mathrm{S}}$ ба $\mathrm{E}$ нь газрын гадаргуу дээр хэмжигддэг ба давтамжийн функц байдлаар төлөөллийн эсэргүүцлийн утгыг гаргаж авдаг. Цахилгаан орны хүчлэг, Е нь гадаргуу дээр L зайд хос электрод хоорондын потенциалын ялгаврыг вольтметрээр хэмждэг $\left(E=\frac{\Delta \mathrm{U}}{\mathrm{L}}\right)$. Цахилгаан орны хүчлэг ба соронзон индукцийн утгаас төлөөллийн эсэргүүцлийн утгыг Тэгшитгэл 3-аар тооцно. 


$$
\rho_{x y}(T)=0,2 T\left|Z_{x y}\right|^{2}=0.2 T\left|\frac{E_{x}}{H_{y}}\right|^{2} \text { [Ом.м] }
$$

МТ - ийн хэмжилтээр цахилгаан орны хүчлэг, соронзон орны индукц ба фазыг хугацааны функц байдлаар бичиж авдаг. Үүнийг боловсруулж төлөөллийн эсэргүүцлийн утгыг гаргаж авдаг. Боловсруулсан мэдээллээ ашиглан шууд бодлого бодуулж тухайн орчинд хамгийн сайн тохирох нэг хэмжээст загварыг гаргаж авдаг. Дараа нь инверс бодуулж гүн дэх үе бүрийн зузаан ба зузаанд харгалзах эсэргүүцлийн утгаас тогтох нэг хэмжээст эсэргүүцлийн загварыг гаргаж авдаг.

МТ аргын мэдээлэл боловсруулалтанд скин гүн ба статик шилжилт гэсэн хоёр асуудлыг мөн шийддэг.

\section{Скин гүн (Skin depth)}

Скин гүн гэдэг нь гадаргуу дээр цахилгаан соронзон орон е-1 - ээр буурсанаар тодорхойлогддог гүн юм. Энэ нь хугацааны орны өөрчлөлт дэх эсвэл дэлхий рүҮ цахилгаан соронзон долгион хэр гүнд нэвтэрч буйг үнэлэхэд зориулсан уртын хуваарь мэтээр ашиглагддаг.

$$
\delta=500 \sqrt{\rho \mathrm{T}}
$$

Энд, $\delta$ - скин гүн (м);

$\mathrm{T}-\mathrm{Ye}$ (сек);

$\rho-$ эсэргүүцэл (Ом.м)

Скин гүн нь үеэс хамаардаг. Тиймээс, нам давтамжийн дохио нь өндөр давтамжтай дохионоос илүү гүн рүү нэвтэрдэг [4].

Статик шилжилт (Static shift)

Гадаргуу дээрх цахилгаан орныг хэмждэг бүх эсэргүүцлийн аргууд нь төлөөллийн эсэргүүцлийн үл мэдэгдэх үржүүлэгч байдлаар илэрдэг теллурын шилжилтийн асуудал эсвэл статик шилжилтийн асуудалтай байсаар байдаг. Соронзон теллурын аргад цахилгаан

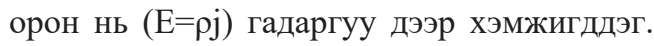
Үүнд топограф ба гүйдлийн гажуудал нөлөөлдөг. Хүчдэлийн ялгавар гадаргуу дээр бүртгэгдэхэд үе давхарга дунд өндөр эсэргүүцэлтэй биет байвал гүйдэл нь бага эсэргүүцэлтэй хэсгээр гүйхийг эрмэлздэг. Хэвтээ үеийн дагуу гүйдэл гүйнэ гэж үзвэл энэ нь гүйдлийн гажуудал үүсгэдэг. Топографын хэлбэрээс болоод өндөршил ихтэй газар гүйдлийн нягт бага байх ба муруй нь доошоо шилждэг гэхдээ өндөршил багатай газар гүйдлийн нягт их гараад дээшээ шилждэг. Соронзон теллурын аргын статик шилжилтийн асуудал нь соронзон теллурын хэмжилттэй ойр зайд хэмжигдсэн ТЕМ эсэргүүцлийн муруйтай харьцуулснаар засагддаг. ТЕМ арга нь хэмжилт эхлэхээс өмнөх хугацаанд л гадаргууд ойр эсэргүүцлийн бүтэц болон өндөршилийн өөрчлөлтөнд мэдрэмтгий байдаг. ТЕМ нь хугацааны сүүлч үед хэмжигддэг.

\section{ТЕМ БА МТ ХЭМЖИЛТИЙН МЭДЭЭЛЛИЙН НЭГ ХЭМЖЭЭСТ ДАВХАР ИНВЕРС}

ТЕМ боловсруулалт нь тэжээлийн гүйдэл огцом зогссоны дараа хугацааны функц байдлаар бичигдсэн хүчдэлийн утгаас төлөөллийн эсэргүүцлийг хугацааны функц хэлбэрээр гаргаж авдаг. МТ аргын хэмжигдсэн утга болох хугацааны функц байдлаар бичигдсэн цахилгаан орны хүчлэг, соронзон индукц ба фазыг боловсруулсны дараа үеийн функц хэлбэртэй төлөөллийн эсэргүүцэл гарч ирдэг. Инверсийн үр дүнд хөрсний эсэргүүцлийн нэг хэмжээст загвар гарч ирдэг. Үүнийг давхар инверсд ашиглахад МТ статик шилжилтийн асуудал ТЕМ аргын мэдээлэл боловсруулалтын үр дүнгийн тусламжтайгаар засагддаг. ТЕМ and МТ давхар инверсийн үр дүнгийн жишээг Зураг 2 - т үзүүлэв. 


\section{EYF009_3283}
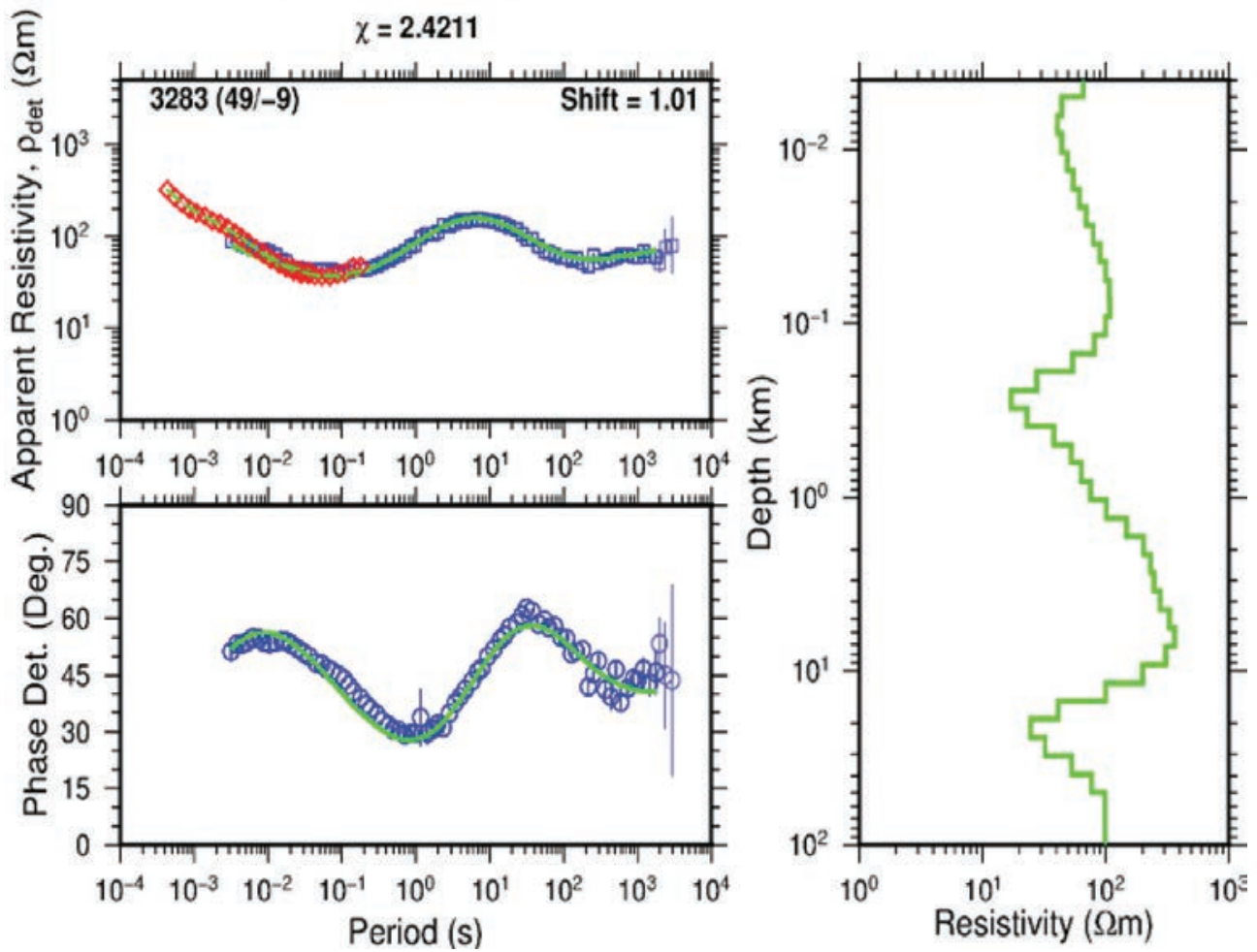

Зураг 2: TEM (3283) and MT (EYF009) хэмжилтүYдийн нэг хэмжээст давхар инверсийн үр дүн. Энд, улаан дөрвөлжсин ТЕМ хэмжсилтийн төлөөллийн эсэргүҮилийн утгууд; иэнххр дөрвөлжингөөр МТ хэмжилтийн төлөөллийн эсэргүүилийн утгууд; иэнхэр бөөрөнхий дүрсээр МТ импеданс тензорын тодорхойлогчоос гарч ирсэн төлөөллийн эсэргүуилийн утгууд; баруун тальнн ногоон зураас нь 1D давхар инверсийн загварыг үзүүлсэн; Зургийн дээд хэсэгт нэр нь МТ ба TEM хэмжилтүҮдийн дугаар ба загварын алдааны утга ұ байна. МТ - ийн хэмжилтийн утгыг ТЕМ -ийнхтэй ижил түвшинд авч ирэхэд хийсэн шилжилтийн утга 1.01.

\section{СУДАЛГААНЫ ҮР ДУН}

\section{Эсргүүцлийн хөндлөн зүсэлт ба гүний зүсэлтүуд}

Зураг3 ба4-тТЕМбаМТ хэмжилтүүдийн нэг хэмжээст давхар инверсийн үр дүн дээр үндэслэсэн Эйяафёрдур талбайн өөр өөр гүнд эсэргүүцлийн хөндлөн зүсэлтүүдийг үзүүлсэн. 

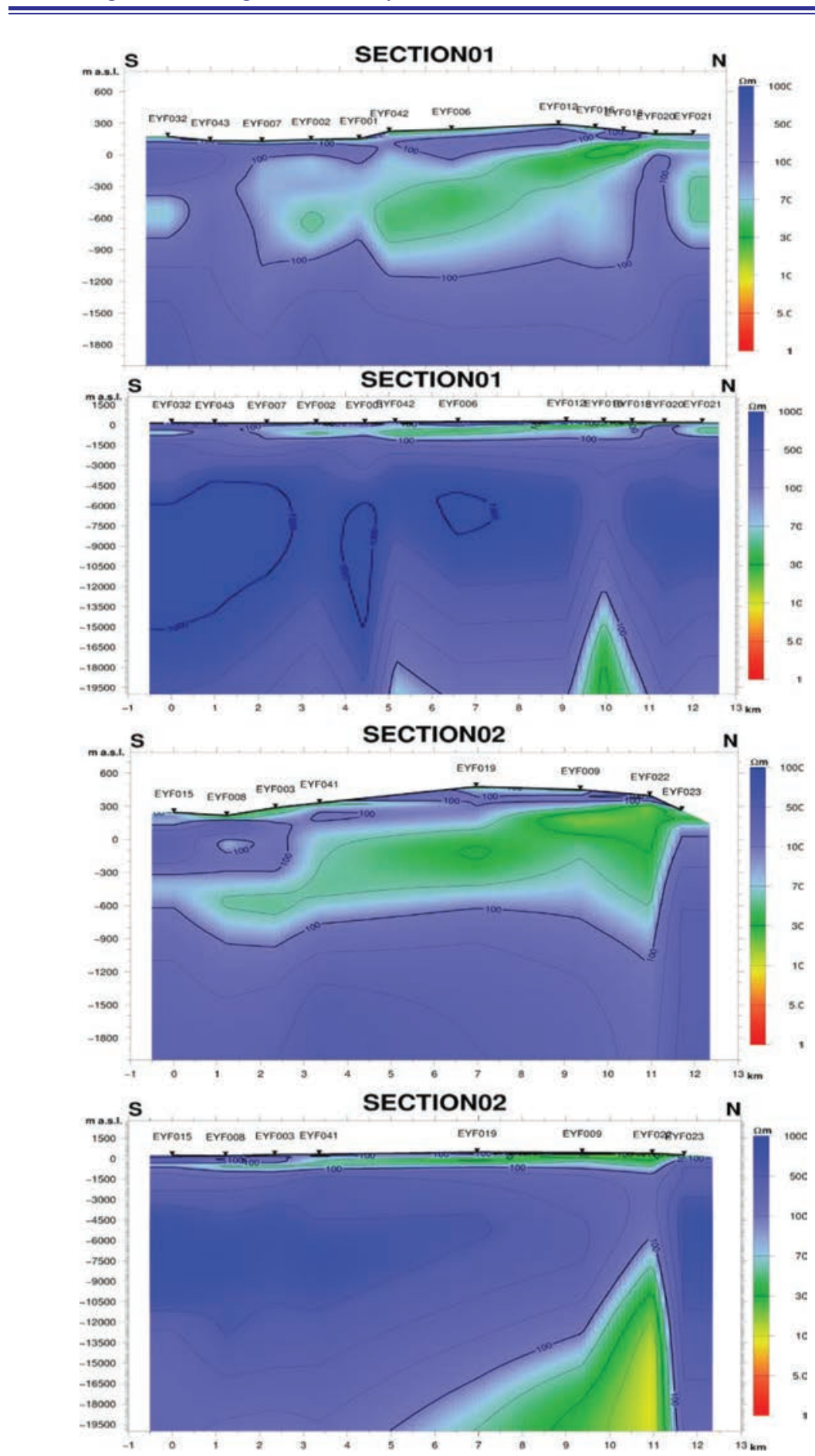

Зураг 3. N01 шугамын дагуу доош 2,000 ба 20,000 м гүнүүд хүртэлх эсэргүүилийн хөндлөн зүсэлт. Хар гурвалжингууд нь МТ хэмжсилтийн иэгүүд. Хөндлөн зүсэлтийн шугамын чиглэлийг зураг 1 УзУҮлсэн. 
Эсэргүүцлийн хөндлөн зүсэлт нь гадаргуугаас 1000 м хүртэлх гүний бага эсэргүүцэлтэй биетийг илүY гүнд буюу хэдэн километрийн гүнд хоёр дахь бага эсэргүүцэлтэй биет хоёр хөндлөн зүсэлт дээр хоёуланд илэрсэн. Эдгээр эсэргүүцлийн бүтэц нь 4 - р зурагт үзүүлсэн гүний зүсэлтээс ч харагдаж байна.
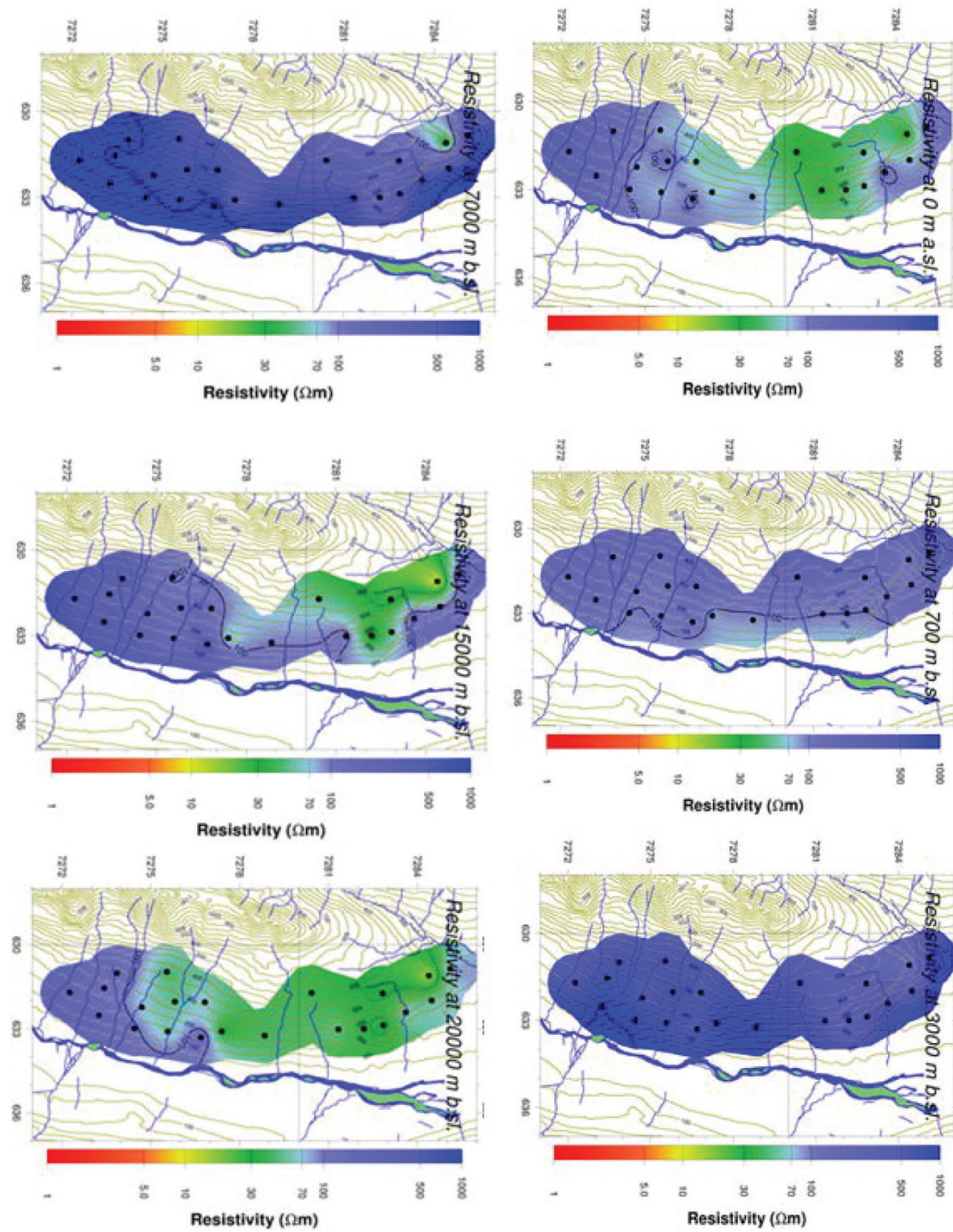

Зураг 4. Далайн түвшинд буюу 0, далайн түвшнээс доош 700, 3000, 7000, 15000, 20000 м гүнүУд дэх эсэргүҮилийн зусэлт. 
Бага гүнд илэрсэн бага эсэргүүцэлтэй биетийн хамрах талбай нь гүн рүүгээ багассаар үзэгдэхээ болих ба нилээд гүнээс

\section{ДУГНЭЛТ}

Геофизикийн судалгаанд 2 - оос дээш хэд хэдэн аргууд хосолсон байдлаар ашиглагддаг. Энэ судалгаанд ТЕМ ба МТ аргуудыг хослуулан хэрэглэж хэмжилтийн мэдээллийг боловсруулж, инверсийн аргаар гүний нэг хэмжээст эсэргүүцлийн загварыг гаргасан. Эсэргүүцлийн гүний болон хөндлөн зүсэлтүудийн хоёр хэмжээст загварыг давхар инверсийн аргын үр дүнг ашиглан зурагласан. Хойноос урагш чиглэсэн эсэргүүцлийн хөндлөн зүсэлтийн үр дүнг өмнө нь Flóvenz and Karlsdóttir (2000) нарын хийсэн TEM хэмжилтийн үр дүн болон бусад судалгааны эхэлсэн бага эсэргүүцэлтэй биет нь 20000 км - ээс их гүнд өргөн талбайг хамран оршиж байна.

ажлуудаар хийгдсэн хэмжилтийн үр дүнтэй харьцуулан баталсан. Үүнд Flóvenz and Karlsdóttir (2000) нарын тодорхойлсноор 300 - 800 м гүнд бага эсэргүүцэлтэй үе нь налуу үелсэн галт уулын чулуулгийн дагуу гадаргуу дээр гарч ирсэн. Мөн бага гүнд илэрсэн бага эсэргүүцэлтэй үе нь форфирит ба тунаж тогтсон давхарга дотор холилдсон толэйтик лаваас бүрдсэн ба газрын гүний дулаан гадаргуу дээр гарч ирэх бүс гэж тайлбарлагдсан нь температурын гажлаар батлагдсан байсан. Харин агуулагч чулуулгийн буюу дэвсгэр утга нь толэйтик лава төрлийн чулуулгуудаас тогтсон гэжээ.

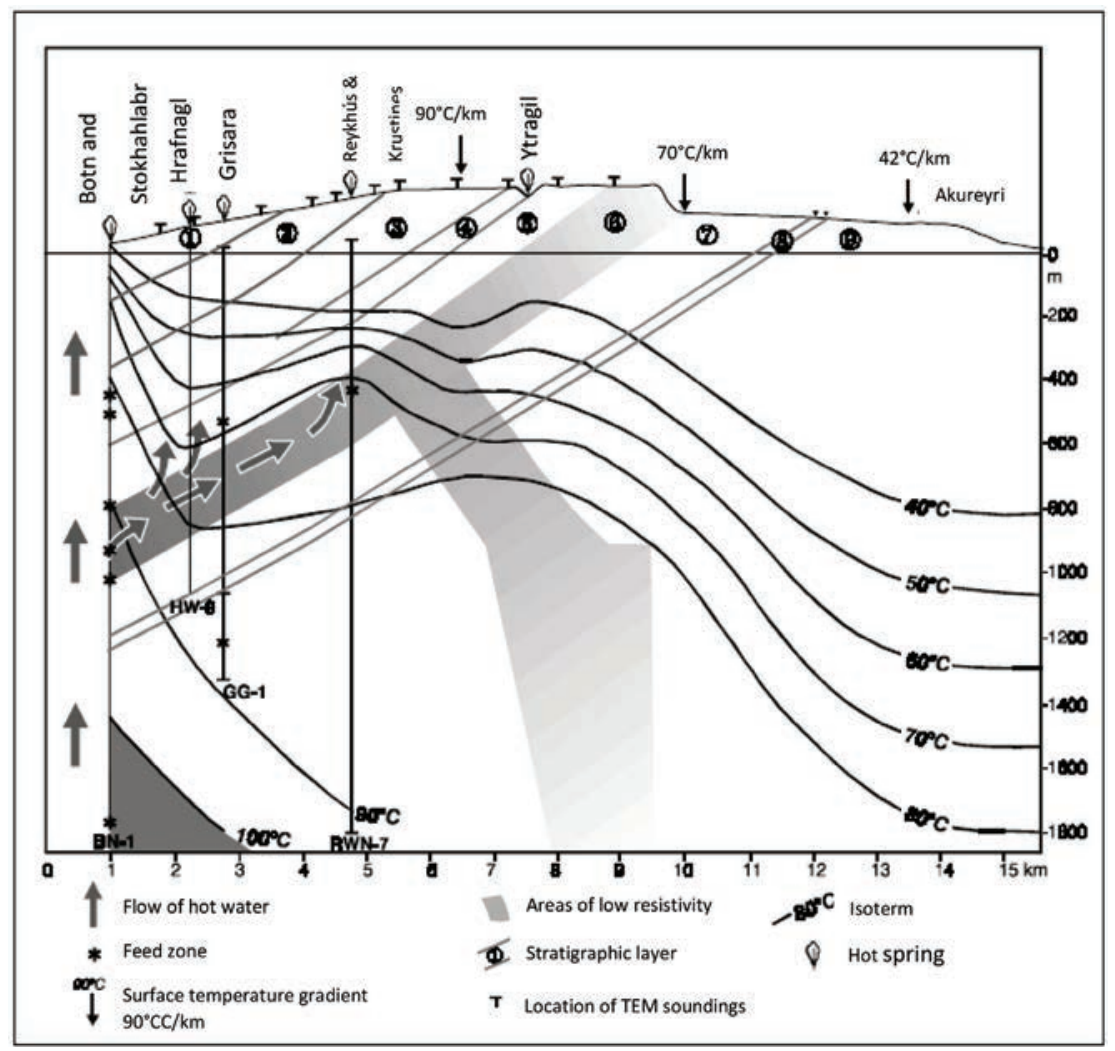

3ураг 5. Flyvenz and Karlsdottнr, 2000 нарын Эйяафёрдур талбайн газрын гүний дулааны эх ҮҮсвэрийн бүтэи, байрлальн тайлал 
Эсэргүүцлийн гүний зүсэлтүүд ба хөндлөн зүсэлтүүдээс бага эсэргүүцэлтэй үе нь хойшоо, ба газрын гадаргуу руу чиглэлтэй үргэлжилсэн ба далайн түвшинээс дээш 200 м-т хөндлөн зүсэлтийн гадаргуугийн дагуух шугамын 11.5 км-т гадаргуу дээр гарч ирсэн. Хөндлөн огтлол01 дээр 12000 м гүнд, хөндлөн огтлол02 дээр 6000 м гүнд илэрсэн бага эсэргүүцэлтэй үе нь Исландын ихэнх газрын гүний дулааны талбайд илэрдэгтэй адил байсан. Эдгээр бага эсэргүүцэлтэй бага гүний болон их гүний үе давхаргууд бидний судалгаагаар зураглагдсан нь өмнөх судалгааны үр дүнтэй тохирч байна.

Эсэргүүцлийн судалгааны аргуудыг ашиглан дэлхийн гүний эсэргүүцлийн бүтцийг гүн болон эсэргүүцлийн хамаарлын функц байдлаар зурагласан. Газрын гүний дулааны эх үүсвэрийн талбайд эсэргүүцэл нь газрын гүний дулааны эх үүсвэрийн нөөцийг агуулах хэсгийн шинж чанарыг илэрхийлж чадах параметрүүдэд хүчтэй хариу үйлдэл үзүүлж байдаг. Газрын гадаргуу дээрх эсэргүүцлийн судалгаа нь дэлхийн гүний чулуулгийн эсэргүүцлийн бүтцийг шууд тандан судлахад хэрэглэгддэг. Энэ нь газрын гүний дулааны эх Үүсвэрийн нөөцийн усан сангийн шинж чанарын нөхцлүүдийг урьдчилан хэлэхэд олон давуу талтай. Өөрөөр хэлбэл эсэргүүцлийн судалгааны гол ач холбогдол нь газрын гүний дулааны эх үүсвэрийн идэвхжилтийн оношилгоо болдог ба газрын гүний дулааны эх үүсвэрийн бодит байдлын талаарх ойлголтыг өгдөг.

\section{НОМ ЗУЙ}

1. Flyvenz, Y.G., Hersir, G.P., Saemundsson, K., Ermannsson, H., and Fridriksson Th., 2012: Geothermal energy exploration techniques. In: Sayigh, A. (ed.), Comprehensive renewable energy, vol. 7. Elsevier,Oxford, 51-95.

2. Ernason, K., 1989: Central-loop transient electromagnetic sounding over a horizontally layered earth.Orkustofnun, Reykjavнk, report OS-89032/JHD-06, 129 pp.

3. Keary, P., Brooks, M., Hill, I.,2002: An introduction to geophysical exploration. Blackwell Scientific Publications, Oxford, 254 pp.

4. Hersir, G.P., and Bju̧rnsson, A., 1991: Geophysical exploration for geothermal resources. Principlesand applications. UNU-GTP, Iceland, report 15, 94 pp.

5. Flyvenz Y.G. and Karlsdyttir, R., 2000: TEM-resistivity image of a geothermal field in $N$-Iceland and the relation of the resistivity with lithology and temperature. Proceedings of the World Geothermal Conference 2000, Kyushu - Tohoku, Japan, 1127-1132. 


\title{
RESISTIVITY SURVEYING IN GEOTHERMAL EXPLORATION WITH AN APPLICATION TO THE EYJAFJORDUR LOW TEMPERATURE AREA, NORTH ICELAND
}

\author{
Sarantsetseg L. ${ }^{1 *}$, Hersir G.P. ${ }^{2}$, Arnason K. ${ }^{2}$ \\ 1. Institute of Astronomy and Geophysics of MAS \\ 2. Iceland Geosurvey-ISOR \\ *corresponding author mail: sarantsetseg@iag.ac.mn
}

\begin{abstract}
Geothermal exploration involves geology, geochemistry and geophysics. In geophysical exploration, resistivity surveying plays a most important role in delineating the reservoir. The parameters that control the geothermal system show a strong response to electrical resistivity. The resistivity methods that are mostly used in geothermal exploration in Iceland are TEM (Transient electromagnetics) and MT (Magnetotellurics). The resulting resistivity cross sections and resistivity depth slices, show a shallow lying low resistivity layer and deep lying low resistivity towards the end of the cross sections.
\end{abstract}

Keywords: geothermal, resistivity, magnetotellurics; 